\title{
A PROBABILISTIC MODEL OF REGIONAL-SCALE RESPONSE TO EXTREME STORM EVENTS
}

\author{
Tomas Beuzen, University of New South Wales, Australia, t.beuzen@unsw.edu.au \\ Kristen D. Splinter, University of New South Wales, Australia, k.splinter@unsw.edu.au \\ Ian L. Turner, University of New South Wales, Australia, ian.turner@unsw.edu.au \\ Mitchell D. Harley, University of New South Wales, Australia, m.harley@unsw.edu.au \\ Lucy A. Marshall, University of New South Wales, Australia, lucy.marshall@unsw.edu.au \\ Margaret L. Palmsten, Naval Research Laboratory, USA, meg.palmsten@nrlssc.navy.mil \\ Hilary F. Stockdon, US Geological Survey, USA, hstockdon@usgs.gov \\ Nathaniel G. Plant, US Geological Survey, USA, nplant@usgs.gov
}

\section{INTRODUCTION}

Predicting beach erosion caused by extreme storms remains a key focus of the coastal engineering community, having important implications for both emergency and long-term coastal management and planning. In June 2016, an extra-tropical cyclone impacted the east coast of Australia, resulting in the largest erosion event recorded in this region for several decades. High-resolution data collected during this event included immediate pre and post-storm airborne LIDAR measurements of the subaerial beach along 400 $\mathrm{km}$ of coastline, as well as detailed modeling of inshore wave conditions. This unprecedented data set presents a unique opportunity to explore key drivers of the observed local and regional variability in the response of beaches to extreme storm events.

Bayesian Networks (BNs) are data-driven probabilistic models that are increasingly being used in coastal engineering. Their application provides new methods to investigate the morphological variability in coastline response to storms. BNs quantify systems using conditional probabilities and work by identifying the generic relationships between hydrodynamic and morphodynamic variables.

This study uses a BN to identify the key drivers of the magnitude and local/regional variability in rapid morphological changes caused by the June 2016 storm along the east coast of Australia. The BN is then used to model the observed morphological response to major erosion events at various other international sites across the USA and Europe, where similar high-resolution data is available, to investigate the generic transferability of the BN developed for the east coast of Australia.

\section{METHODOLOGY}

High-resolution topographic measurements of the morphological response along $400 \mathrm{~km}$ of the east
Australian coastline to the June 2016 storm were quantified by repeat airborne LIDAR obtained within one week before and after this event. This data comprised 1768 cross-shore profile transects, spaced every $100 \mathrm{~m}$ alongshore, from which morphological characteristics were extracted. The corresponding hydrodynamic forcing at each individual transect was simulated from a regional wave model of the event and verified against available Waverider buoys within the study area.

The observed morphological response at every $100 \mathrm{~m}$ spaced transect was characterised by three key variables: berm erosion volume (i.e. between MSL and the dune toe), dune erosion volume and horizontal dune toe recession. To identify the key drivers of the observed variability in these features, 12 morphological and hydrodynamic variables encompassing the antecedent conditions of the beach and wave \& water-level forcing were tested in a Bayesian Network (BN) through an iterative sensitivity analysis. The input variables that explained the most variability in the data set were included in a final BN (Figure 1) which was used to model the observed morphological response to the June 2016 storm as well the response of other international sites to major erosion events including Hurricane Ivan (Santa Rosa Island, USA) and the 2013-2014 Western Europe Storms (southwest UK).

\section{RESULTS \& DISCUSSION}

Results reveal that up to $80 \%$ of the morphological response to the June 2016 storm could be explained using a BN with only 4 input variables (Figure 1): prestorm berm volume, peak total water level, cumulative nearshore wave power and dune width. Application of this $\mathrm{BN}$ to major erosion events at Santa Rosa Island, USA, and the southwest UK reveal the degree to which these input-response variable relationships identified for the east coast of Australia can be used to generalise and predict beach erosion at other locations.

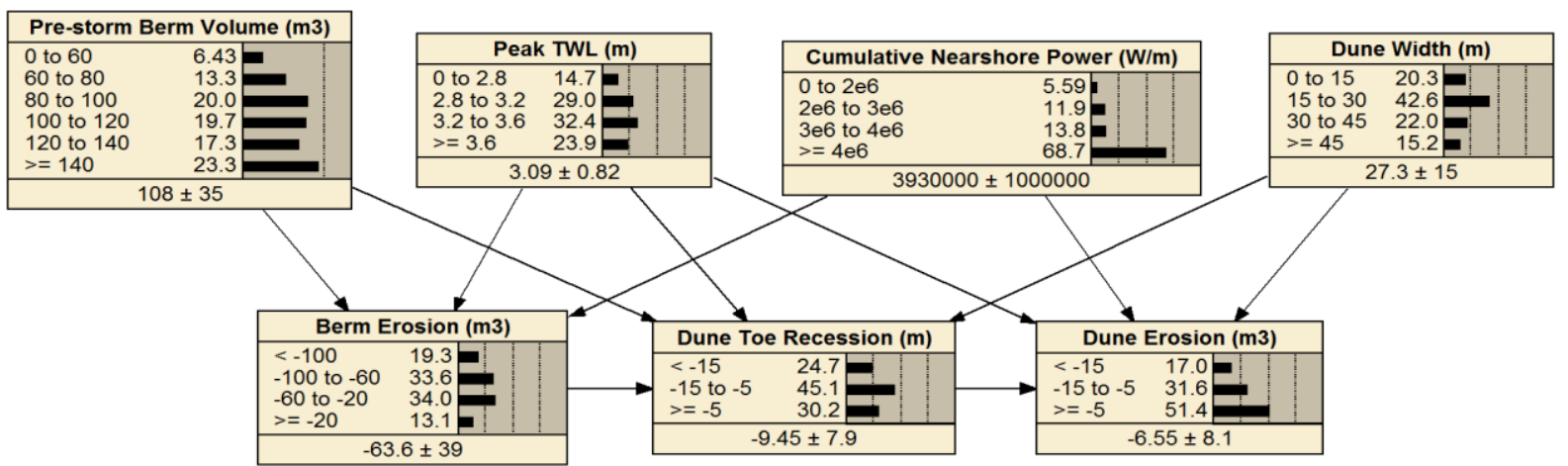

Figure 1 - The Bayesian Network developed from the June 2016 storm data. Four input variables (pre-storm berm volume, peak total water level, cumulative nearshore wave power, dune width) can predict up to $80 \%$ of the variability of the response variables berm erosion, dune toe recession and dune erosion. 